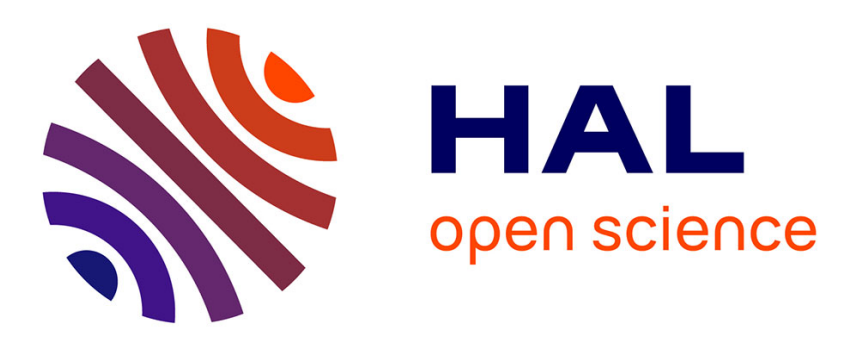

\title{
On the Application of Fiber-Reinforced Materials of Low Density in Construction Elements Subjected to High Loads
}

H. Lehr, E. Lach, U. Wiese, A. Bohmann

\section{- To cite this version:}

H. Lehr, E. Lach, U. Wiese, A. Bohmann. On the Application of Fiber-Reinforced Materials of Low Density in Construction Elements Subjected to High Loads. Journal de Physique IV Proceedings, 1997, 07 (C3), pp.C3-553-C3-558. 10.1051/jp4:1997395 • jpa-00255552

HAL Id: jpa-00255552

https://hal.science/jpa-00255552

Submitted on 1 Jan 1997

HAL is a multi-disciplinary open access archive for the deposit and dissemination of scientific research documents, whether they are published or not. The documents may come from teaching and research institutions in France or abroad, or from public or private research centers.
L'archive ouverte pluridisciplinaire HAL, est destinée au dépôt et à la diffusion de documents scientifiques de niveau recherche, publiés ou non, émanant des établissements d'enseignement et de recherche français ou étrangers, des laboratoires publics ou privés. 


\title{
On the Application of Fiber-Reinforced Materials of Low Density in Construction Elements Subjected to High Loads
}

\author{
H.F. Lehr, E. Lach, U. Wiese and A. Bohmann \\ French-German Research Institute of Saint-Louis (ISL), 5 rue Général-Cassagnou, 68301 Saint-Louis, \\ France
}

\begin{abstract}
Fibre reinforced materials with low densities have been examined in order to find substitutes for high strength aluminium which is used for some ammunition sabot elements being subjected to short duration high stresses. These materials were polymers and magnesium alloys reinforced with short-fibres. As fibre material glass as well as carbon and aluminium-oxide was taken. Quasi-static and dynamic compression tests were performed at strain rates from $10^{-4} / \mathrm{s}$ to $10^{3} / \mathrm{s}$ with both materials. The mechanical properties of the fibre-reinforced magnesium alloys were also compared to their matrix materials. Experiments proved the applicability of the fibre-reinforced sabot elements at mass gains of about $30 \%$.
\end{abstract}

Résumé. On a examiné des matériaux renforcés par fibres de faible densité en vue de trouver des produits de substitution à l'aluminium à haute résistance utilisé pour certains éléments de sabots de munitions soumis à des contraintes élevées pendant une durée courte. Ces matériaux étaient des polymères et des alliages de magnésium renforcés par des fibres courtes. Comme matériau de fibres, on a choisi aussi bien le verre que le carbone et l'alumine. Des tests de compression quasistatique et dynamique ont été effectués avec des vitesses de déformation de $10^{-4} / \mathrm{s}$ à $10^{3} / \mathrm{s}$ avec les deux matériaux. Les propriétés mécaniques des alliages d'aluminium renforcés par fibres ont été comparées à leur matériaux de matrice. Les expériences montrent le plein fonctionnement avec les éléments de sabot renforcés par fibres résultant dans un gain de masse d'env. $30 \%$.

\section{INTRODUCTION}

The construction elements of kinetic energy ammunition are subjected to short duration high stresses as a results of acceleration loads. A typical example is the sabot of a subcaliber projectile by the aid of which the gas forces acting in the gun barrel must be transformed in the most efficient manner in order to give the bighest possible kinetic energy to the payload. The element must assure structural integrity and safety against failure at a minimum of mass, especially as the sabot must be looked at as dead mass with no contribution to the main effect. Therefore the best suited materials for that purpose are those of low density and high loading capacity.

It is the purpose of our work to test some special materials with the above mentioned properties in order to prove their applicability in that respect as an alternative to the standard high strength aluminium.

\section{MATERIAL TESTS EXPERIMENTAL SET-UP}

Dynamic compression tests were performed on a split-Hopkinson-pressure-bar (SHPB). The bars are of maraging steel with a diameter of $20 \mathrm{~mm}$ and a length of $1000 \mathrm{~mm}$. Projectiles are flat ended so that the rise time of the incident signal is very small. The specimens were lubricated with a lubricant on carbon basis. The diameter of the specimens was $12 \mathrm{~mm}$ or $14 \mathrm{~mm}$ at a length of $8 \mathrm{~mm}$ or $10 \mathrm{~mm}$ respectively.

\section{MATERIALS}

\subsection{Polymer-Matrix Composites}

Two kinds of polymer-matrix composites were investigated. These are short-length fibres reinforced thermoplastic composites and glass-fibre reinforced epoxy-resin-matrix composites.

The matrix of short-length fibre reinforced thermoplastic composites consists either of polyamid or of polyetheretherketon. Polyetheretherketon was reinforced with 30 weight-\% short-length carbon fibres.' 
Polyamid was reinforced with 20 weight- $\%$ and 30 weight- $\%$ short-length glass-fibres. Mechanical properties can be seen in table 1 .

Table 1: Mechanical properties of short-length fibre reinforced plastics.

\begin{tabular}{|c|c|c|c|c|c|}
\hline & Density & Yield stress & Elongation & Flexural strength & Elastic mod. \\
\hline & g/cm 3 & $\mathrm{MPa}$ & $\%$ & $\mathrm{MPa}$ & GPa \\
\hline PEEK/30\% CF & 1.44 & 208 & 1.3 & 318 & 13 \\
\hline PA6.6/20\% GF & 1.23 & 220 & 3 & 320 & 16 \\
\hline PA6.6/30\% GF & 1.35 & 200 & 3.5 & 280 & 0.97 \\
\hline
\end{tabular}

The glass-fibre reinforced epoxy-resin-matrix composite consists of parallel oriented e-glass rovings and epoxy-resin. Epoxy-resin contents are 35 weight-\% or 50 vol.-\%. Mechanical properties are in table 2.

Table 2: Mechanical properties of glass-fibre reinforced epoxy-resin-matrix composite.

\begin{tabular}{|c|c|c|c|c|}
\hline Density & Flexural strength & Failure strain & Tensile strength & Elastic mod. \\
\hline $2.0 \mathrm{~g} / \mathrm{cm} 3$ & $900 \mathrm{MPa}$ & $<2 \%$ & $900 \mathrm{MPa}$ & $36 \mathrm{GPa}$ \\
\hline
\end{tabular}

\subsection{Magnesium-Matrix Composite and Magnesium Alloys}

A magnesium matrix composite and two magnesium alloys were investigated. The two magnesium alloys are the matrix alloy AZ91 and AZ31. Chemical compositions of studied magnesium alloys can be seen in table 3.

Table 3: Chemical composition of studied magnesium alloys.

\begin{tabular}{|c|c|c|c|c|}
\hline & Al [\%] & $\mathrm{Zn} \mathrm{[ \% ]}$ & $\mathrm{Mn}[\%]$ & Balance \\
\hline \hline AZ91 & 9 & 0.7 & 0.2 & $\mathrm{Mg}$ \\
\hline AZ31 & 3 & 1 & 0.3 & $\mathrm{Mg}$ \\
\hline
\end{tabular}

The magnesium matrix composite consists of AZ91 reinforced with short-length fibres of aluminium oxide. Aluminium oxide fibres of type Saffil (producer ICI) turned out to be most adequate to reinforce light metals. It was found out that contents of $20 \%$ fibres are optimal [1]. Composition and properties of Saffil-fibres can be seen in table 4. It is important that contents of $\mathrm{SiO}_{2}$ are very small, because it reacts with magnesium melts.

Short-length fibres are manufactured to preforms. Then they are infiltrated with a melt of AZ91 by squeeze casting. Squeeze casting allows rapid solidification which is required in case of very reactive magnesium melts. Fibres lead to grain refinement of matrix alloy so that in composites grain sizes are smaller.

Table 4: Chemical composition and properties of Saffil fibre

\begin{tabular}{|c|c|}
\hline Composition & $96-97 \% \mathrm{Al2O} 3 / 3-4 \% \mathrm{SIO2}$ \\
\hline Crystal structure & $\delta-\mathrm{Al203}, \mathrm{parts}$ of $\alpha-\mathrm{Al203}$ \\
\hline Tensile strength & $2000 \mathrm{MPa}$ \\
\hline Elastic modulus & $300 \mathrm{GPa}$ \\
\hline Density & $3.3 \mathrm{~g} / \mathrm{cm} 3$ \\
\hline Diameter of fiber & $3 \mu \mathrm{m}$ \\
\hline
\end{tabular}

Mechanical properties drawn by quasistatic tensile tests of magnesium alloys are in table 4 . Fibre reinforcement does not strongly increase tensile resistance and it decreases strain to failure.

Table 5: Mechanical properties of investigated magnesium alloys drawn by tensile test.

\begin{tabular}{|c|c|c|c|c|c|}
\hline & Rp0.2 & Rm & A & Elastic modulus & Density \\
\hline \hline AZ91/20\% Al2O3 & $240 \mathrm{MPa}$ & $311 \mathrm{MPa}$ & $1-2 \%$ & $56 \mathrm{GPa}$ & $2 \mathrm{~g} / \mathrm{cm} 3$ \\
\hline AZ91 & $170 \mathrm{MPa}$ & $270 \mathrm{MPa}$ & $4.50 \%$ & $40-45 \mathrm{GPa}$ & $1.8 \mathrm{~g} / \mathrm{cm} 3$ \\
\hline AZ31 & $160 \mathrm{MPa}$ & $225 \mathrm{MPa}$ & $10 \%$ & & $1.77 \mathrm{~g} / \mathrm{cm} 3$ \\
\hline
\end{tabular}

Quasistatic compression tests showed that Saffil-fibre reinforcement augments compression resistance to about $550 \mathrm{MPa}$ compared with $300 \mathrm{MPa}$ of unreinforced alloy. Strain to failure amount to $6 \%$. A reinforcement with short-length fibres mainly improves compression resistance.

The compression resistance of Saffil-fibre reinforced AZ91 is comparable to high strength aluminium alloys. The density of magnesium composite is increased by Saffil-fibres to $2 \mathrm{~g} / \mathrm{cm}^{3}$ (table 5). This is still a lower density than these of aluminium alloys at about $2.7 \mathrm{~g} / \mathrm{cm}^{3}$. 


\section{COMPRESSION TESTS}

The materials described in chapter 3 were subjected to dynamic compression tests (SHPB). Results of magnesium alloys can be seen in fig.1. The increased dynamic compression strength of fibre reinforced AZ91 attracts attention. It reaches about $650 \mathrm{MPa}$ compared with the unreinforced matrix alloy AZ91 of

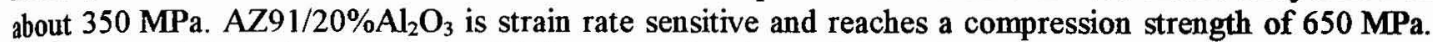
The strain to failure also amount to $6 \%$ like at quasistatic condition. Fig. 2 represents the results of fibre reinforced polymers and AZ91. Compression tests were performed at strain rates of $7001 / \mathrm{s}$ to $800 \mathrm{1} / \mathrm{s}$. The flow curves of glass-fibre reinforced epoxy can only be used to describe the tendency. Deformations up to 3\% measured by SHPB are not correct. Reinforced epoxy possesses the highest compression resistance but the lowest strain to failure. Short-length fibre reinforced thermoplastics only reach a compression resistance of about $250 \mathrm{MPa}$. The percentage of glass-fibres influences the compression resistance of PA.

\section{ACCELERATION TESTS}

\subsection{Experimental Configuration}

As already mentioned acceleration experiments had to be performed with the fibre reinforced materials in order to prove their applicability under service conditions. Therefore we decided to exchange elements of a special sabot concept against the fibre reinforced materials.

The standard sabot is made of an aluminium alloy ( $\mathrm{AlZnMgCu} 1,5)$. Fig.3 shows a model type sabot with 4 petals as used to accelerate heavy metal rods in a. $40 \mathrm{~mm}$ smooth bore gun. Acceleration forces from the sabot to the rod are transmitted by the thread. The serration between the sabot petals serve as additional safety and sealing device.

Another hybrid-type sabot concept consists of 8 elements, 4 of which form an inner ahuminium cone being arranged in a hull made of fibre reinforced plastic (Crastin, PBTB with $30 \%$ glass long fibres), see fig.4. By this construction principle it is also possible to accelerate the heavy metal rod without any thread nor grooves only by friction forces [2]. This sabot concept is of course much better suited than the standard sabot for substitution of the aluminium against other materials and to test these materials under practical service conditions [3]. Therefore the inner cone elements of the sabot were made of the magnesiummatrix composite and the polymer-matrix composite respectively. A heavy metal rod of $8 \mathrm{~mm}$ diameter and $150 \mathrm{~mm}$ length with a mass of $140 \mathrm{~g}$ was chosen as payload. The rod/sabot assembly was then accelerated by means of a powder gun thereby applying gas pressures of more than 5000 bar corresponding to accelerations well above $10^{6} \mathrm{~m} / \mathrm{s}^{2}$. Test results can be observed by the aid of X-ray photographs which were taken about $1,5 \mathrm{~m}$ downrange the muzzle.

\subsection{Magnesium-Matrix Composite and Magnesium Alloys}

As we have seen the magnesium-matrix composite ( $\mathrm{AZ91}$ with $20 \% \mathrm{Al}_{2} \mathrm{O}_{3}$ ) is strain rate sensitive and reaches a relatively high compression strength of $650 \mathrm{MPa}$. Therefore it seems to be well suited for our purpose as according to the special sabot construction the cone elements are mainly subjected to compression loads.

As an example fig. 5 shows the result of an experiment with the Saffil-fibre reinforced sabot elements. The picture shows the rod together with the sabot elements just coming off. One can clearly distinguish between the 4 metallic parts of the inner cone and the outer polymer elements. The picture proves that the magnesium-matrix composite elements do withstand the high loads. In a series of experiments gas pressures from 3200 bar to 5350 bar and hence accelerations from $0.9^{*} 10^{6} \mathrm{~m} / \mathrm{s}^{2}$ to $1.4^{*} 10^{6} \mathrm{~m} / \mathrm{s}^{2}$ could be attained without any failure. Therefore there is a quite positive outcome in terms of secure sabot function as well as reproduction of the experimental results.

This is the more interesting as all the tests performed with unreinforced magnesium material were not successful at all. Because of low material strength the cone elements showed strong deformations so that it was not anymore possible to transmit the acceleration forces from the sabot to the rod. 


\subsection{Polymer-Matrix Composites}

As seen from the material tests the polymer-matrix composite with parallel oriented long fibres should also be a material candidate for the cone elements. But of course here the fibre orientation has a strong influence and must be taken into account. To attain best results the fibres should be oriented as close as possible in the same direction as the main stress, i.e.

* in a plane perpendicular to the symmetry axis all the fibres should point to the centre,

$*$ in an axial plane the fibres should be inclined to the axis (with an angle of about $60^{\circ}$ ).

This can of course only be obtained with a great number of cone elements which causes other specific disadvantages. The solution chosen was a cone consisting of 6 elements (instead of 4 as in the tests men-
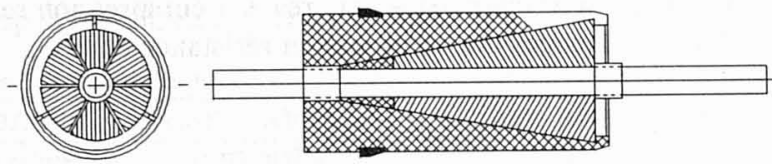

Fig.6: Model sabot with G.R.P. cone elements tioned above) being machined out of a com. posite plate containing the parallel oriented long fibres. The sketch of fig.6 shows the sabot arrangement, the hatching drawn in the cone elements giving the orientation of the glass fibres. A cut-off model of the acceleration unit can be seen in fig.7; clearly visible are the rod as well as the 6 inner cone segments and the single-part outer sabot element (with breaking points).

An X-ray photograph of an experiment with the glass-fibre reinforced sabot elements is shown in fig.8. From the picture it is evident that the cone elements did withstand the load so that the rod could be accelerated without any problems. It is also clearly visible that the outer sabot element is split up in several small parts (as could be expected). There are very similar results for all the tests being performed in about the same pressure and acceleration range as mentioned above. Yet a delamination of the matrix composite can be observed which is the more evident the higher the gas pressure rises, compare fig.9. Despite these findings the delamination in no case turned out to be a disadvantage: even with some sabot elements broken in several pieces no failure could be observed in any of these experiments as far as the acceleration of the payload is concerned. Therefore the model sabot out of $100 \%$ composite material did meet the main task and showed very encouraging results.

\section{FINAL REMARKS}

The investigations described above demonstrated the applicability of some fibre-reinforced materials such as magnesium and epoxy in a high stress / high acceleration environment. The laboratory compression tests proved the sensitivity to strain rate and a relatively high compression strength. The acceleration experiments showed the applicability of these materials under the before mentioned conditions. Compared to the aluminium material being used for the cone elements there was a mass gain of about $30 \%$ which results in a mass gain of $15-20 \%$ relative to the entire element.

\section{REFERENCES:}

[1] Kainer, K.U., Magnesium-Alumina Composites - Production and Properties, Proceedings Verbundwerk 1990

[2] Wiese, U., Lehr, H.F., Schirm, V., Guth, P., 'Untersuchung zur Treibspiegeltechnologie: Treibring in Kompositbauweise für Pfeilgeschosse mit Form- und Reibschluß', ISL RT 504/88 (1988)

[3] Lehr, H.F., Schirm, V., 'Geschoßkonzepte', in: 'Ballistische Forschung im ISL (1945-1994)', Saint-Louis 1994 

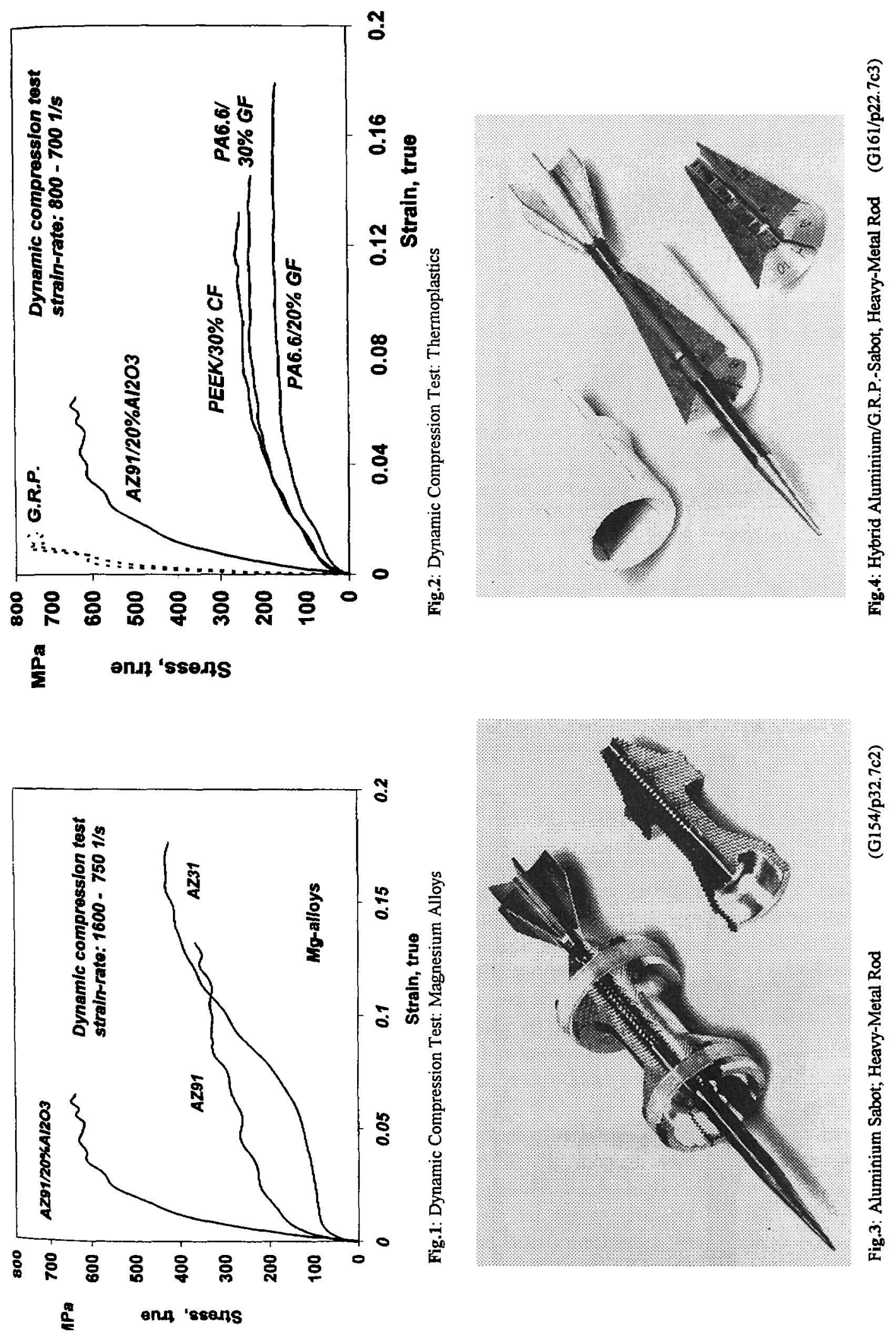

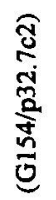

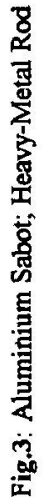



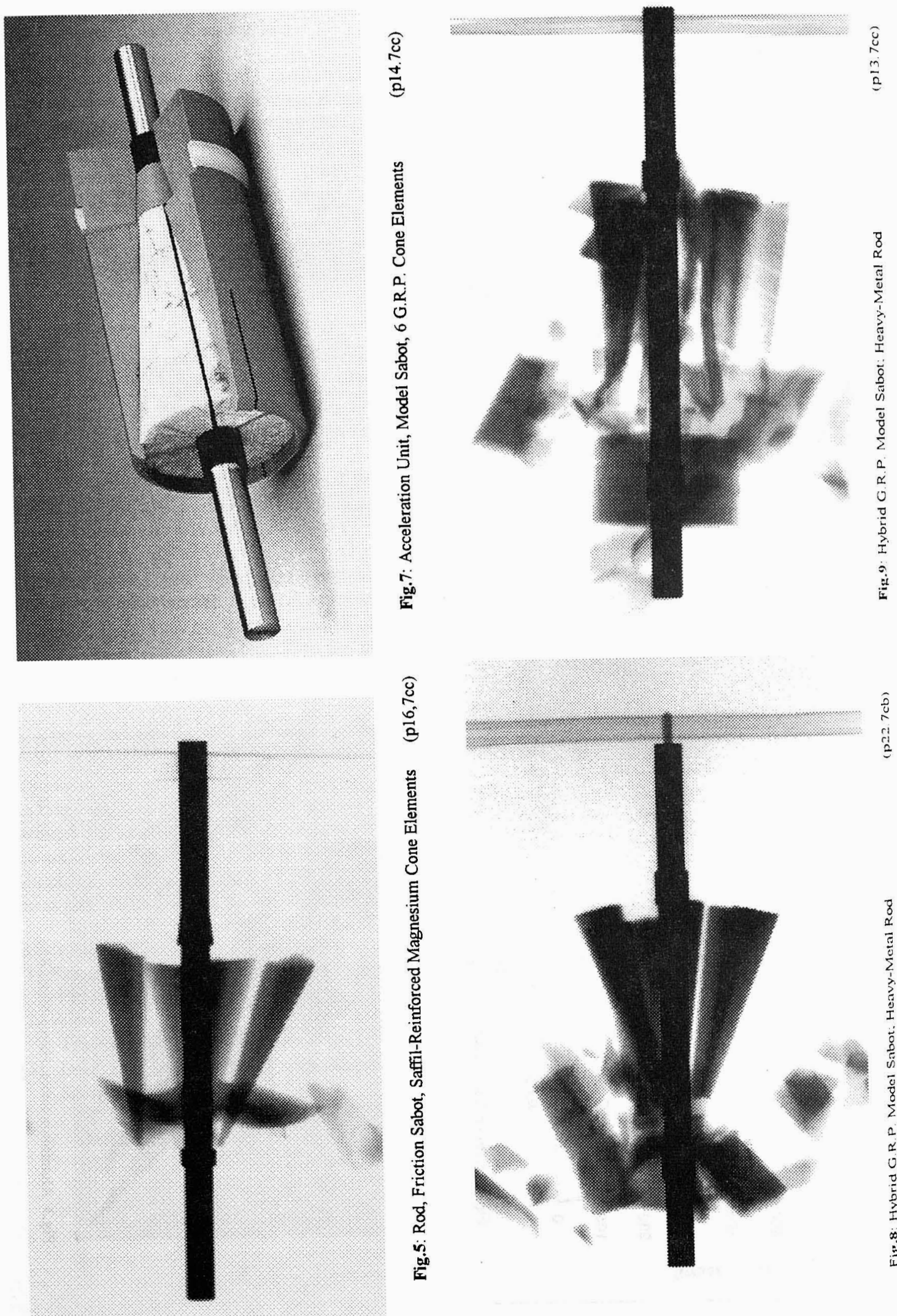

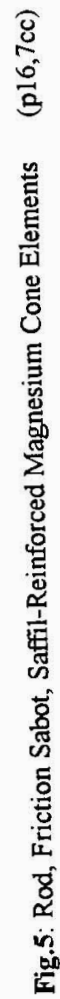

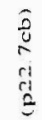

